\title{
Analysis of five streptokinase formulations using the euglobulin lysis test and the plasminogen activation assay
}

L.T. Couto,

J.L. Donato and G. de Nucci
Departamento de Farmacologia, Faculdade de Ciências Médicas, Universidade Estadual de Campinas, Campinas, SP, Brasil

\section{Correspondence}

\section{G. de Nucci}

Departamento de Farmacologia

Faculdade de Ciências Médicas

UNICAMP

13084-970 Campinas, SP

Brasil

Fax: +55-19-3242-7439

E-mail: denucci@dglnet.com.br

Presented, as a poster, at the XXXV Congresso Brasileiro de

Farmacologia e Terapêutica Experimental, Águas de Lindóia, SP, Brazil, September 21-24, 2003.

Publication supported by FAPESP.

Received November 28, 2003 Accepted August 31, 2004

\begin{abstract}
Streptokinase, a 47-kDa protein isolated and secreted by most group A, C and G B-hemolytic streptococci, interacts with and activates human protein plasminogen to form an active complex capable of converting other plasminogen molecules to plasmin. Our objective was to compare five streptokinase formulations commercially available in Brazil in terms of their activity in the in vitro tests of euglobulin clot formation and of the hydrolysis of the plasmin-specific substrate S-2251 ${ }^{\mathrm{TM}}$. Euglobulin lysis time was determined using a 96-well microtiter plate. Initially, human thrombin $(10 \mathrm{IU} / \mathrm{ml})$ and streptokinase were placed in individual wells, clot formation was initiated by the addition of plasma euglobulin, and turbidity was measured at 340 $\mathrm{nm}$ every $30 \mathrm{~s}$. In the second assay, plasminogen activation was measured using the plasmin-specific substrate S- $2251^{\mathrm{TM}}$. Streptase ${ }^{\mathrm{TM}}$ was used as the reference formulation because it presented the strongest fibrinolytic activity in the euglobulin lysis test. The Unitinase ${ }^{\mathrm{TM}}$ and Solustrep ${ }^{\mathrm{TM}}$ formulations were the weakest, showing about $50 \%$ activity compared to the reference formulation. All streptokinases tested activated plasminogen but significant differences were observed. In terms of total S-2251 ${ }^{\mathrm{TM}}$ activity per vial, Streptase ${ }^{\mathrm{TM}}$ (75.7 \pm 5.0 units $)$ and Streptonase ${ }^{\mathrm{TM}}(94.7 \pm 4.6$ units $)$ had the highest activity, while Unitinase ${ }^{\mathrm{TM}}\left(31.0 \pm 2.4\right.$ units) and $\operatorname{Strek}^{\mathrm{TM}}(32.9 \pm 3.3$ units) had the weakest activity. Solustrep ${ }^{\mathrm{TM}}(53.3 \pm 2.7$ units $)$ presented intermediate activity. The variations among the different formulations for both euglobulin lysis test and chromogenic substrate hydrolysis correlated with the SDS-PAGE densitometric results for the amount of $47-\mathrm{kDa}$ protein. These data show that the commercially available clinical streptokinase formulations vary significantly in their in vitro activity. Whether these differences have clinical implications needs to be investigated.
\end{abstract}

Key words - Streptokinase

- Plasminogen

- Plasmin

- Substrate S-2251 ${ }^{\mathrm{TM}}$ 


\section{Introduction}

In 1933, Tillet and Garner (1) first described the exogenous plasminogen activator isolated and secreted by most group A, C and $\mathrm{G} \beta$-hemolytic streptococci. This activator was named "streptokinase" by Christensen and MacLeod (2). Streptokinase, a 47-kDa protein, interacts with the protein plasminogen to form a streptokinase-plasminogen complex capable of converting other plasminogen molecules to plasmin. Streptokinase does not require fibrin for efficient plasminogen activation in blood (3). It is a catalytically inert bacterial protein that has no structural homologues $(4,5)$. Streptokinase can form an activator complex with plasmin, which contains a functional active site, or with plasminogen (lys-plasminogen) in which it induces non-proteolytically the formation of a functional active site $(5,6)$.

The success of the complex formed by streptokinase as a therapeutic agent has been attributed to its unique mechanism of fibrindependent plasminogen activation. When administered to humans, the streptokinase activator complex rapidly generates plasmin in the circulating blood at sites distant from fibrin clots. This mechanism depletes the plasminogen substrate and exhausts the clotdissolving (or fibrinolytic) potential of plasminogen (7-9).

Streptokinase is now a leading agent for the treatment of acute myocardial infarction. Approximately 400,000-500,000 patients

Table 1. Streptokinase formulations for clinical use evaluated in the present study.

\begin{tabular}{lll}
\hline Name & Streptokinase supplier & Lot No. \\
\hline Streptase & Hoechst Marion Roussel S/A & $2482601 \mathrm{~F}$ \\
Unitinase & Meizler Comércio Internacional S/A & 717102 \\
Solustrep & Laboratório Químico Farmacêutico Bergamo Ltda. & DK0456 \\
Streptonase & Blausiegel Ind. \& Com. Ltda. & KH07K150 \\
Strek & Libra Produtos Laboratoriais Ltda. & 717102 \\
\hline
\end{tabular}

These streptokinase preparations are commercially available in Brazil and are identified by the commercial name, manufacturer and specific lot number. All formulations nominally contained 1,500,000 IU of fibrinolytic activity per vial. receive thrombolytic therapy per year worldwide. Many investigators (10-15), based on several randomized multicenter clinical trials, recommend 1,500,000 IU as the appropriate dose for the treatment of an acute myocardial infarction. From a clinical perspective, the possible effect of significant deviations from the recommended dose is unknown. Note that the assays reported here were not the same as used for the recommendation of 1,500,000 IU.

Five streptokinase preparations commercialized in Brazil for clinical use by different manufacturers were analyzed to determine their activity, content and homogeneity. Streptase ${ }^{\mathrm{TM}}$ was used as a reference material. The activity of the samples was determined on the basis of euglobulin lysis time and of a chromogenic assay using S-2251 ${ }^{\mathrm{TM}}$. The homogeneity of the protein content of the samples was determined by SDS-PAGE.

The study revealed significant differences among commercially available preparations in Brazil in terms of total streptokinase activity per vial.

\section{Material and Methods}

\section{Streptokinase}

Five streptokinase preparations from different manufacturers, containing 1,500,000 IU per vial as a powder, were tested (Table 1). Five milliliters of cold Milli-Q water was added to each flask to dissolve the solid. Samples nominally containing 300,000 IU/ $\mathrm{ml}$ were frozen at $-70^{\circ} \mathrm{C}$ until use. During analysis all solutions were immersed in ice.

\section{Preparation of human plasma and euglobulin fraction}

Blood was obtained by venipuncture from the antecubital vein of 2 healthy volunteers at rest, with minimum stasis. Samples were collected into a 0.1 volume of $3.8 \%$ sodium citrate and plasma was prepared by centrifu- 
gation $(2,000 \mathrm{~g})$ for $15 \mathrm{~min}$ at $4^{\circ} \mathrm{C}$. Plasma samples were pooled and kept at $-70^{\circ} \mathrm{C}$ until use.

The plasma euglobulin fraction was prepared by 10 -fold dilution of citrated plasma and acidification at $\mathrm{pH} 5.0$ by the addition of $1 \%$ acetic acid. After standing for $1 \mathrm{~h}$ at $4^{\circ} \mathrm{C}$ the diluted plasma was centrifuged $(2,000 \mathrm{~g})$ for $15 \mathrm{~min}$ at $4^{\circ} \mathrm{C}$. The precipitate was dissolved in $0.1 \mathrm{M}$ Tris- $\mathrm{HCl}$ buffer, $\mathrm{pH}$ 7.4.

\section{Euglobulin clot lysis assay}

We used a 96-well microtiter plate assay to determine the euglobulin lysis time (1618). Control samples were prepared by adding $20 \mu \mathrm{l}$ human thrombin $(10 \mathrm{IU} / \mathrm{ml})$ and 30 $\mu \mathrm{l} 0.1 \mathrm{M}$ Tris-HCl buffer, $\mathrm{pH} 7.4$, to individual wells. Test samples were prepared by adding $10 \mu \mathrm{l}$ thrombin, $10 \mu \mathrm{l}$ buffer and 20 $\mu 1$ streptokinase solution. Clot formation was initiated by the addition of $150 \mu \mathrm{l}$ of the plasma euglobulin fraction. The turbidity in the wells was measured as absorbance at $340 \mathrm{~nm}$ every $30 \mathrm{~s}$ for $20 \mathrm{~min}$ using a SPECTRAmax Microplate Spectrophotometer and the software SOFTmax PRO (Molecular Devices Corporation, Sunnyvale, CA, USA). Each streptokinase dilution was assayed in triplicate. To evaluate the effect of the different streptokinases on euglobulin lysis time, we used the software GraphPad Prisma 3.0 to plot the log of streptokinase IU against log of the area under the curve. Linear regression was applied and the efficiency of each streptokinase formulation was compared to the reference Streptase ${ }^{\mathrm{TM}}$.

To evaluate the streptokinase activity after storing the stock solution, the fibrinolytic activity was also evaluated after $24 \mathrm{~h}$ at $4^{\circ} \mathrm{C}$.

\section{Chromogenic assay}

Plasminogen activation by streptokinase was assayed using the synthetic substrate S2251 ${ }^{\mathrm{TM}}$ (Chromogenix-Instrumentation Laboratory, Milan, Italy). S-2251 ${ }^{\mathrm{TM}}$ is a chromo- genic substrate for both plasmin and streptokinase-activated plasminogen. The method for the determination of activity is based on the difference in absorbance between the pNA formed and the original substrate. The rate of pNA formation is measured at 405 $\mathrm{nm}$ and this photometric signal is directly proportional to the plasmin activity, which reflects the amount of functional plasminogen originally present in the sample.

The reaction was performed using 96well plates. Control samples were prepared by adding $20 \mu \mathrm{l} 0.1 \mathrm{M}$ Tris- $\mathrm{HCl}$ buffer, $\mathrm{pH}$ $7.4,30 \mu \mathrm{l}$ substrate $\mathrm{S}-2251(0.6 \mathrm{mM})$ and $100 \mu$ l plasminogen solution $(0.1 \mathrm{CU} / \mathrm{ml})$. In the test samples the reaction was performed after addition of $20 \mu \mathrm{l}$ streptokinase solution tested at different concentrations ( 150 to 600 IU/ml), $30 \mu \mathrm{l} \mathrm{S}-2251$ and $100 \mu \mathrm{l}$ plasminogen solution. The plate was immediately placed in the plate reader previously heated at $37^{\circ} \mathrm{C}$. The absorbance of the wells was measured at $405 \mathrm{~nm}$ every $30 \mathrm{~s}$ for $30 \mathrm{~min}$. Plates were shaken for $3 \mathrm{~s}$ before reading the absorbance using a SPECTRAmax Microplate Spectrophotometer and the software SOFTmax PRO. Each streptokinase dilution was assayed a minimum of three times.

One unit was defined as the amount of enzyme activity that converts $1 \mu \mathrm{mol}$ of substrate per minute per liter. Since the enzymatic activity is normally calculated using a cuvette with $1 \mathrm{~cm}$ of optical path, we adapted the formula to the 96-well plate taking into account a total reaction volume of 150 $\mu l$ and an optical path of $0.4 \mathrm{~cm}$. Under these conditions, the extinction coefficient of pNA is $3840 \mathrm{~mol} \mathrm{l}^{-1} \mathrm{~cm}^{-1}$.

\section{Polyacrylamide gel electrophoresis}

Samples were prepared for SDS-PAGE analysis by diluting $50 \mu \mathrm{l}$ of each streptokinase stock solution in $950 \mu \mathrm{l}$ Milli-Q water. Finally, $100 \mu \mathrm{l}$ of the diluted streptokinase solution was mixed with $100 \mu \mathrm{l}$ of 2 X Laemmli buffer (19). Samples were heated at $95^{\circ} \mathrm{C}$ 
for 4 min to complete the reaction with the SDS and B-mercaptoethanol and $20 \mu \mathrm{l}$ of each sample was loaded onto the stacking gel. PAGE was performed using a discontinuous system (19). Samples were initially loaded and stacked in $4 \%$ polyacrylamide gel (stacking gel). Proteins were resolved in $10 \%$ polyacrylamide gel (resolving gel). SDS was used in combination with $\beta$-mercaptoethanol to reduce disulfide bonds, denature the proteins and make the proteins negatively charged. Electrophoresis was conducted at $20 \mathrm{~mA}$ per gel (100-200 V) until the bromophenol blue marker reached the bottom of the gel. Proteins were stained with Coomassie brilliant blue solution $(0.025 \%$

Table 2. Comparison of streptokinase activity measured by euglobulin lysis in five clinical formulations.

\begin{tabular}{lcc}
\hline Streptokinase & $\begin{array}{c}\text { Streptokinase activity }(\%) \\
\text { relative to Streptase }\end{array}$ & $\begin{array}{c}\text { Loss of streptokinase } \\
\text { activity after } 24 \mathrm{~h} \text { at } 4^{\circ} \mathrm{C}(\%)\end{array}$ \\
\hline Streptase $^{\mathrm{TM}}$ & 100 & $62.0 \pm 4.7$ \\
Streptonase $^{\mathrm{TM}}$ & $83.3 \pm 15.8$ & $63.3 \pm 9.5$ \\
Strek $^{\mathrm{TM}}$ & $71.6 \pm 15.6$ & $70.2 \pm 3.0$ \\
Solustrep $^{\mathrm{TM}}$ & $52.2 \pm 10.6$ & $49.9 \pm 6.7$ \\
Unitinase $^{\mathrm{TM}}$ & $46.8 \pm 2.4$ & $59.0 \pm 3.3$ \\
\hline
\end{tabular}

Activity was measured by the euglobulin lysis test and is reported as percent of the activity present in the Streptase ${ }^{\mathrm{TM}}$ formulation. Data are reported as the mean $\pm \mathrm{SEM}$ for three independent experiments performed in duplicate. The data for the stability study at $4^{\circ} \mathrm{C}$ for $24 \mathrm{~h}$ represent the total loss (\%) of the fibrinolytic activity compared to the values reported in the first column.

Table 3. Comparison of streptokinase activity measured by the hydrolysis of the chromogenic peptide S-2251 $\mathrm{TM}$

\begin{tabular}{lccc}
\hline Streptokinase & Total units & Ratio to the reference Streptase & N \\
\hline Streptonase $^{\mathrm{TM}}$ & $94.7 \pm 4.6$ & 1.25 & 16 \\
Streptase $^{\mathrm{TM}}$ & $75.7 \pm 5.0$ & 1.00 & 14 \\
Solustrep $^{\mathrm{TM}}$ & $53.3 \pm 2.7$ & 0.70 & 15 \\
Strek $^{\mathrm{TM}}$ & $32.9 \pm 3.3$ & 0.43 & 14 \\
Unitinase $^{\mathrm{TM}}$ & $31.0 \pm 2.4$ & 0.41 & 12 \\
\hline
\end{tabular}

Plasminogen activation induced by streptokinase was measured spectrophotometrically with S-2251 ${ }^{\mathrm{TM}}$, a substrate for both plasmin and streptokinase-activated plasminogen. One unit is defined as the amount of enzyme activity that converts $1 \mu \mathrm{mol}$ of substrate per minute per liter. Each of the streptokinase formulations tested was compared to the reference Streptase ${ }^{\mathrm{TM}}$. Results are reported as the mean \pm SEM for the number of determinations shown in the right column.
Coomassie blue in $10 \%$ acetic acid) for at least $1 \mathrm{~h}$, then destained with $10 \%$ acetic acid for $2 \mathrm{~h}$. Mobility was plotted against the molecular weight of standard proteins (SigmaMarker Wide Range, Sigma, St. Louis, MO, USA) using a semi-log scale and the molecular weight of the proteins was estimated by interpolation.

Densitometric analysis of the protein bands was performed using the software Scion Image for Windows (Scion Corporation, Frederick, MD, USA).

\section{Protein quantification}

Total protein concentration was determined with the QuantiPro ${ }^{\mathrm{TM}} \mathrm{BCA}$ assay kit (Sigma) using bovine serum albumin as standard (20).

\section{Results and Discussion}

\section{Euglobulin clot lysis}

Clot formation was observed immediately after starting the reaction and turbidity increased until clot lysis was initiated by activated plasmin. The resulting graph was a hyperbole and the area under the curve increased with decreasing streptokinase concentration. Since the lines obtained were not perfectly parallel, we performed the comparison using 100 points covering the total line length. The relative streptokinase activity is represented as the mean $\pm \mathrm{SD}$ of these 100 points.

Streptase ${ }^{\mathrm{TM}}$ showed the strongest fibrinolytic activity in the euglobulin lysis test. Unitinase $^{\mathrm{TM}}$ and Solustrep ${ }^{\mathrm{TM}}$ were the weakest proteins, showing about $50 \%$ of the activity of the Streptase ${ }^{\mathrm{TM}}$ formulation (Table 2). The data show a more than $50 \%$ difference in activity between the most active (Streptase ${ }^{\mathrm{TM}}$ ) and least active (Unitinase ${ }^{\mathrm{TM}}$ ) streptokinase preparations as measured by euglobulin clot lysis. Streptokinase activity decreased dramatically after $24 \mathrm{~h}$ at $4^{\circ} \mathrm{C}$ (Table 2). 


\section{Hydrolysis of S-2251 ${ }^{\mathrm{TM}}$}

All streptokinase preparations tested hydrolyzed the plasminogen-like synthetic peptide substrate. However, the activity varied amongst the streptokinase formulations, as indicated in Table 3. Streptonase ${ }^{\mathrm{TM}}(94.7 \pm$ 4.6 units/vial) and Streptase ${ }^{\mathrm{TM}}(75.7 \pm 5.0$ units/vial) were the most active formulations, while Strek $^{\mathrm{TM}}$ and Unitinase ${ }^{\mathrm{TM}}$ were the weakest $(32.9 \pm 3.3$ and $31.0 \pm 2.4$ units/vial, respectively). Solustrep ${ }^{\mathrm{TM}}(53.3 \pm 2.7$ units/ vial) presented intermediate activity (Table 3 ).

\section{SDS-PAGE}

Electrophoretic analysis showed two major bands. The upper band corresponded to human albumin $(\sim 67 \mathrm{kDa})$ and was the most prominent protein (Figure 1A). The lower band was identified as the streptokinase protein on the basis of its apparent molecular mass of $47 \mathrm{kDa}$ (data not shown), Streptase $^{\mathrm{TM}}$, Solustrep ${ }^{\mathrm{TM}}$ and Streptonase ${ }^{\mathrm{TM}}$ showed contaminating proteins of a wide molecular mass range below $67 \mathrm{kDa}$. The bands corresponding to Unitinase ${ }^{\mathrm{TM}}$ and Strek ${ }^{\mathrm{TM}}$ were resolved into two components.

Densitometric analysis of protein bands confirmed a significant variation in the amount of both streptokinase and human albumin protein in each formulation (Figure 1B). The total amount of albumin is only indicated on the label of the following formulations: Unitinase ${ }^{\mathrm{TM}}$ (195 mg), Solustrep $^{\mathrm{TM}}(200 \mathrm{mg})$ and Streptonase ${ }^{\mathrm{TM}}(200$ $\mathrm{mg}$ ). After protein quantitation by three independent determinations the variability observed for total protein amount observed in each flask agreed with the densitometric results: Unitinase ${ }^{\mathrm{TM}}(87.5 \pm 8.5 \mathrm{mg})$, Streptase $^{\mathrm{TM}}(207.1 \pm 9.8 \mathrm{mg})$, Solustrep ${ }^{\mathrm{TM}}$ $(374.0 \pm 32.1 \mathrm{mg})$, Streptonase $^{\mathrm{TM}}(433.3 \pm$ $47.2 \mathrm{mg})$, and Strek $^{\mathrm{TM}}(107.8 \pm 5.1 \mathrm{mg})$.

The amount of protein corresponding to streptokinase is not indicated on the product labels. The variations among the different formulations for both euglobulin lysis test and chromogenic substrate hydrolysis presented a close correlation with the densitometric data for the streptokinase main band (Figure 1B).

The euglobulin lysis test and the chromogenic substrate assay presented similar results in ranking the streptokinase activity of five commercial clinical preparations. This suggests that either assay can be used to determine streptokinase activity. The chromogenic substrate assay has the advantage of being fast and highly reproducible. In the

A

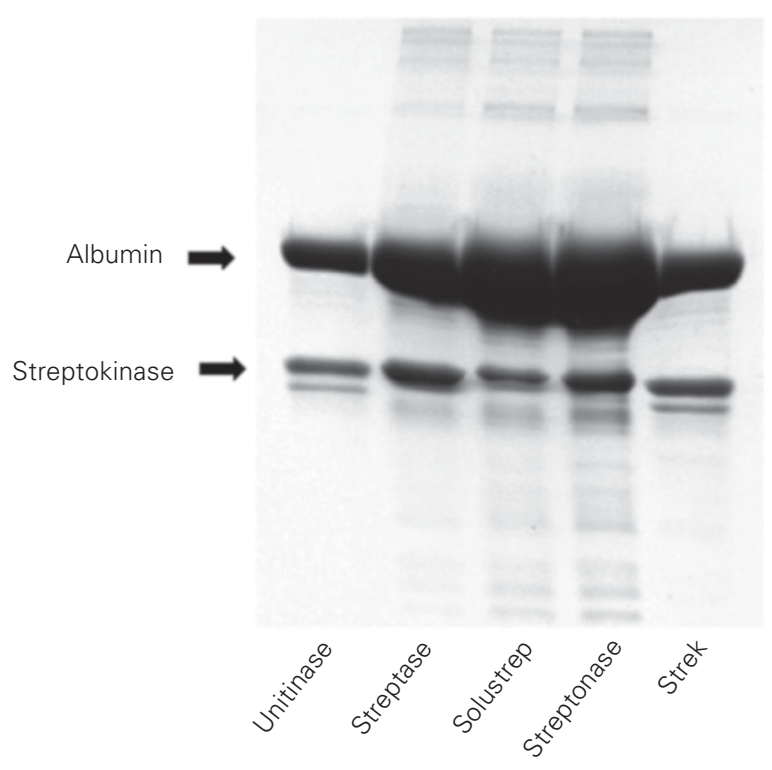

$B$

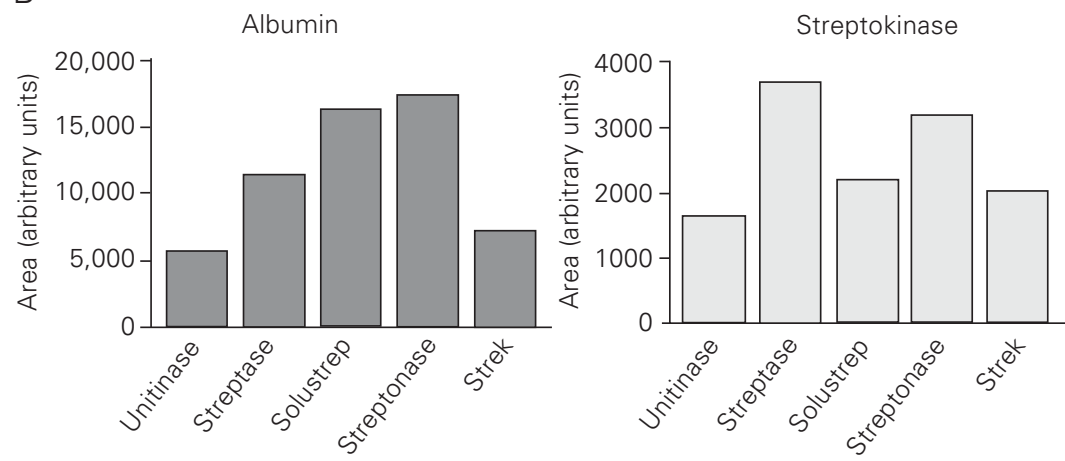

Figure 1. SDS-PAGE analysis of the protein content of five streptokinase formulations. $A$, PAGE was performed using a $10 \%$ polyacrylamide gel in a discontinuous system at $20 \mathrm{~mA}$ per gel $(100-200$ V). Proteins were stained with Coomassie brilliant blue. This result is representative of four independent experiments. $B$, Densitometric analysis of the albumin and streptokinase bands. The areas of the bands are reported in arbitrary units. Note that the scale for albumin is five times that of streptokinase. 
euglobulin test, the preparation of the euglobulin fraction is laborious and this material has also the disadvantage of being unstable.

The present study revealed significant differences among the commercially available streptokinase preparations. Only Streptonase ${ }^{\mathrm{TM}}$ presented similar fibrinolytic activity when compared to Streptase ${ }^{\mathrm{TM}}$. All other streptokinases presented significantly less fibrinolytic activity. There are also significant densitometric differences regarding protein content associated with the SDSPAGE band.

Whether these differences have clinical consequences deserve further evaluation by both medical professionals and regulatory authorities.

\section{References}

1. Tillet WS \& Garner RL (1933). The fibrinolytic activity of hemolytic streptococci. Journal of Experimental Medicine, 58: 485-502.

2. Christensen LR \& MacLeod CM (1945). A proteolytic enzyme of serum: characterization, activation and reaction with inhibitors. Journal of General Physiology, 28: 559-583.

3. Marder VJ \& Sherry S (1988). Thrombolytic therapy: current status (1). New England Journal of Medicine, 318: 1512-1520.

4. Reddy KN \& Markus G (1972). Mechanism of activation of human plasminogen by streptokinase. Presence of active center in streptokinase-plasminogen complex. Journal of Biological Chemistry, 247: 1683-1691.

5. Reddy KN (1988). Streptokinase - biochemistry and clinical application. Enzyme, 40: 79-89.

6. Urano S, Metzger AR \& Castellino FJ (1989). Plasmin-mediated fibrinolysis by variant recombinant tissue plasminogen activators. Proceedings of the National Academy of Sciences, USA, 86: 25682571.

7. Torr SR, Nachowiak DA, Fujii S \& Sobel BE (1992). "Plasminogen steal" and clot lysis. Journal of the American College of Cardiology, 19: 1085-1090.

8. Reed GL, Houng AK, Liu L, Parhami-Seren B, Matsueda LH, Wang S \& Hedstrom $L$ (1999). A catalytic switch and the conversion of streptokinase to a fibrin-targeted plasminogen activator. Proceedings of the National Academy of Sciences, USA, 96: 8879-8883.

9. Collen D \& Lijnen HR (1995). Molecular basis of fibrinolysis, as relevant for thrombolytic therapy. Thrombosis and Haemostasis, 74: 167-171.

10. Wardlaw JM, Zoppo G, Yamaguchi T \& Berge E (2003). Thrombolysis for acute ischaemic stroke. Cochrane Database Systematic Review: CD000213.

11. Jerjes-Sanchez C, Ramirez-Rivera A, Arriaga-Nava R et al. (2001).
High dose and short-term streptokinase infusion in patients with pulmonary embolism: prospective with seven-year follow-up trial. Journal of Thrombosis and Thrombolysis, 12: 237-247.

12. Clase CM, Crowther MA, Ingram AJ \& Cina CS (2001). Thrombolysis for restoration of patency to haemodialysis central venous catheters: a systematic review. Journal of Thrombosis and Thrombolysis, 11: 127-136.

13. Forster $A \&$ Wells $P$ (2001). Tissue plasminogen activator for the treatment of deep venous thrombosis of the lower extremity: a systematic review. Chest, 119: 572-579.

14. Wells PS \& Forster AJ (2001). Thrombolysis in deep vein thrombosis: is there still an indication? Thrombosis and Haemostasis, 86: 499-508.

15. Cannon CP (2000). Exploring the issues of appropriate dosing in the treatment of acute myocardial infarction: potential benefits of bolus fibrinolytic agents. American Heart Journal, 140: S154-S160.

16. Carlson RH, Garnick RL, Jones AJ \& Meunier AM (1988). The determination of recombinant human tissue-type plasminogen activator activity by turbidimetry using a microcentrifugal analyzer. Analytical Biochemistry, 168: 428-435.

17. Beebe DP, Gaffney PJ \& van Schie DM (1992). Potency assays for Anistreplase: comparison of the fibrin plate assay and a 96-well plate assay. Biologicals, 20: 129-133.

18. Marsh NA (1978). Measurement of fibrinolytic capacity by the euglobulin lysis time method - a problem of "units". Thrombosis Research, 12: 197-200

19. Laemmli UK (1970). Cleavage of structural proteins during the assembly of the head of bacteriophage T4. Nature, 227: 680-685.

20. Brown RE (1989). Protein measurement using bicinchoninic acid: elimination of interfering substances. Analytical Biochemistry, 180: 136-139. 